Cilt: 5 Sayı: 1 Yıl: 2021

Voume: 5 Issue: 1 Year: 2021

ULUSLARARASI TICARET VE

EKONOMI ARAŞTIRMALARI

Araştırma Makalesi

Research Article

JOURNAL OF
INTERNATIONAL TRADE AND DERGISi ECONOMIC RESEARCHES

\title{
Did Something Change in Chad after The Oil Era? Evidence from A Rolling-Windows Analysis
}

\author{
Selim Kayhan ${ }^{a^{* *}}$, Abdallatif Mahamat Yacoub ${ }^{b}$ \\ ${ }^{a}$ Prof. Dr., Necmettin Erbakan Üniversitesi, Siyasal Bilgiler Fakültesi, iktisat Bölümü, skayhan @erbakan.edu.tr, 0000-0002-4838-6892. \\ ${ }^{b}$ Doktora Öğrencisi, Necmettin Erba kan Üniversitesi, Sosyal Bil. Ens., Íktisat Bölümü, ben.yacoub.amy@gmail.com, 0000-0002-2896-2653.
}

\section{ARTICLE INFO}

\section{Article History:}

Received May, 20, 2021

Received in revised form July, 6, 2021

Accepted July, 12, 2021

\section{Keywords:}

Chad Economy

Oil Prices

Rolling Windows Analysis

\begin{abstract}
The volatility of oil prices has increased visibly in the last decade. Undoubtedly, the occurrence of volatility a ffects the economics of oil exporting and importing differently. Increases in oil prices positively affect economic indicators in oil exporting economies, while decreases have negative effects. In this regard, increases in volatility have attracted researchers' attention, and a vast literature is found investigating both the economics of oil importing and exporting countries as well as advanced and emerging market economies. The Republic of Chad's economy differs from other economies because of its two different economic eras; the first was an oil import economy, which is energy dependent. The second is its oil era; this started in 2003 when oil reserves were discovered in the country. Due to Chad's unique situation, we have examined the interactions between oil prices and Chad's economic growth performance from 1963 to 2019 to see if its oil revenues have be ne fitted the economy or whether Cha d's situation falls under the "resource curse." The results show that, while oil prices had been negative before the discovery of oil reserves, positive oil prices occurred after 2003. The se prices did become negative again in 2018, which might be a sign of the resource curse.
\end{abstract}

JEL Classifications: Q04, O13, P18.

öz

Petrol fiyatlarındaki oynaklık, son on yılda gözle görülür şekilde artmıştır. Kuşkusuz, dalgalanmanın ortaya çıkması, petrol ihraç ve ithal eden ekonomileri farklı şekilde etkilemektedir. Petrol fiyatların daki artışlar, petrol ihra ca tçısı ekonomilerde ekon omik gös te rgeleri olumlu etkilerken, düşüşler ekonomileri olu msuz etkilemektedir. Bu bağlamda, dalgalanmadaki artışlar a raştırmacıların dikkatini çekmiştir ve hem petrol ithal eden ve ihraç eden ülkelerin ekonomilerini hem de gelişmiş ve yükselen piyasa ek onomilerini a raştıran geniş bir literatür bulunmuştur. Çad Cumhuriyeti'nin ekonomisi, iki farklı ekonomik döneme sahip olmasından dolayı diğer ekonomilerden farklıdır; ilk dönemde, enerjiye bağımlı bir petrol ithala tı ekonomisi iken, ikinci dönem petrol ça ğı olarak a dlandırılmaktadır; bu, 2003 yılında ülkede petrol rezervl erinin keşfedilmesiyle başla mıştır. Çad'ın kendine özgü durumu nedeniyle, petrol gelirlerinin ekonomiye fayda sağlayıp sağlamadığınıveya Ça d'ın durumunun "kaynak laneti" kapsamına girip girmediğini görmek için 1963'ten 2019'a kadar petrol fiyatları ile Çad'ın ekonomik büyüme performansı a rasındaki etkileşimler incelenmektedir. Sonuçlar göstermektedir ki, petrol rezervleri keşfedilmeden önce petrol fiya tla rının Çad ekonomisi üzerindeki etki si negatifiken, 2003 'ten sonra etki pozitifolmuştur. Petrol fiyatının etkisi 2018'de tekrar negatif hale gelmiştir. Bu sonuç "kaynak laneti"nin bir işareti olabilir.

JEL Sınıflandırması: Q04, O13, P18.

\footnotetext{
** Sorumlu ya zar/Corresponding author, skayhan@erbakan.edu.tr 


\section{INTRODUCTION}

Oil price fluctuations in recent years have once again demonstrated how oil price instabilities havesignificant effects on an economy. At the end of 1998, the price of crude oil (West Texas Intermediate) was only $\$ 12$ US a barrel, while reaching $\$ 95$ US by the end of 2007 . Only eight years later, it was again $\$ 37$ US. The annual fluctuations in oil price can be seen in Figure 1.

Figure 1. Annual Fluctuations in Oil Prices (\%).

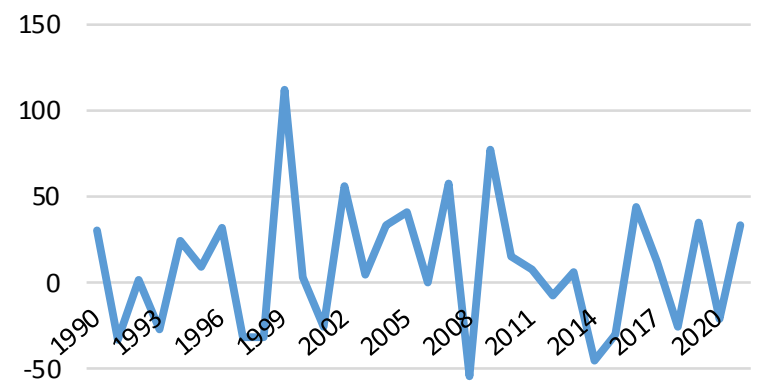

$-100$

Source: Macrotrends (Access date: March 17, 2021)

Numerous studies suggest that fluctuations in oil prices significant affect the economic activity of oil exporting and oil importing countries. These effects vary according to the country's status, as increases in oil prices are good economic indicators for an oilexporting country but bad indicators for an oilimporting country. The opposite occurs with decreases in oil prices (Ghalayini, 2011, p. 127). For an oilexporting country, a rise in oil prices leads to a hike in oil revenues, which causes economic growth, while for an oil importing country, this increase in price raises the current accounts deficit and production costs.

Today, the world oil market is characterized by continuous and unpredictable price instabilities; this naturally creates obvious risks of economic magnitudes such as periods of trade shock, changes in a country's income levels, variable employment and inflation rates, effects on the supply and demand curves of goods, and effects on economic development (Aouzal, 2018, p. 2).

Chad became an oil exporting country after the discovery of oil reserves in 2003. Before its oil era, Chad's economy had been based on agriculture, with cotton as the country's main agricultural output. Its per-capita GDP in 1998 was \$254 US. With the start of its oil projects, its per capita GDP increased to \$331 US in 2003 and reached $\$ 1,025$ US in 2014. Due to the fluctuations in oil prices in recent years, Chad's per capita GDP dropped to $\$ 640$ US in 2020. Despite Chad's rich natural resources, Chad's per capita GDP has fallen. This confirms the literature results that argue countries with vast natural resources to have lower per capita GDPs than countries in need of resources. Despite Chad having rich natural resources, this low per capita GDP can be explained by its poor institutional qualities and low economic diversification.

According to Gylfason (2000), over-dependence on natural resources and agriculture can lead to rentseeking (e.g., corruption) and policy failures (e.g., inflation). It can also slow down economic growth by preventing educational developments and genuine savings from external trade.

Hence, a better understanding of the effects oil price fluctuations have had on Chad's economic activities is very important for the country's authorities. This important information can help authorities apply policies appropriate for avoiding the negative effects of oil price fluctuations and for making positive contributions to Chad's economy.

Although numerous studies are found to have examined the economics of the oil price nexus in different countries, the case of Chad's economy has not been examined much because, different from other economies, Chad's economy as an oil exporting country is brand new, which makes analyzing it more difficult in terms of data. In order to perform an analysis, advanced econometric methods are needed to see how the relation between oil prices and Chad's economic growth has changed over the years by including the discovery of oil reserves in the country. By employing a rolling-window analysis, this study presents a novel examination of the effects oil price fluctuations have had on Chad's economy between 1963 and 2019; this can provide the literature with important information.

The second section summarizes the theoretical framework and existing literature investigating oil prices against economic growth. The third section provides some information about Chad's economy and oil production. The fourth section presents the empirical analysis and results, and the conclusion contains an interpretation of the results in terms of policy implications.

\section{THEORICAL FRAMEWORK AND LITERATURE REVIEW}

Many studies occur explaining how oil price fluctuations can affect the economic activities of oil producing and importing countries. Oil price fluctuations can have significant effects on economic activities in a variety of ways. For an oil-importing country, a rise in oil prices leads to higher production costs and negatively affects economic output. In addition, volatility in oil prices may cause uncertainty and thus affect investment behaviors in future projects (Bernanke, 1983).

With supply-side channels, unexpected increase in oil prices can cause a costly redistribution of labor and capital across industries. Sudden changes in oil prices can transfer resources from industries that use more energy in production or consumption to industries that use less energy. However, this redistribution is costly. 
Therefore, unexpected energy price changes that exceed the share of GDP energy expenditures will have an increased effect on sectors with high redistribution costs (Herrera et al., 2019, p. 90). According to Hamilton (1988), the effects of oil prices from the demand side may similarly result in a costly redistribution of labor and capital across indus tries and significantly affect economic activities.

According to Edelstein and Kilian (2009), oil price fluctuations can create uncertainty in the macroeconomic environment, and this will force households and companies to act more cautiously. As a result, they will reduce their consumption in order to protect real income from falling oil prices. The International Monetary Fund (2015) reported declines in oil prices to have negative economic impacts on oil exporting countries because declining oil prices can upset these countries' current accounts balances, which may negatively affect reserves or lead to exchange rate depreciation.

However, some factors like institutional development, structural flexibility, and financial factors exist that may help oil exporting countries eliminate the negative effects from oil price fluctuations. Economies that depends on the oil sector to generate higher foreign currency reserves or in which the oil industry is more important to the general economy may be more strongly affected by oil price drops. Nonetheless, countries with diversified economic structures are expected to overcome shocks more easily due to nonoil sectors being less affected (Grigoli et al., 2019, p. 482).

The oil crisis of the 1970 s and the recession that followed led to much research on the relationships between oil price fluctuations and macroeconomics. Initial studies (i.e., Rasche \& Tatom, 1977; Darby, 1982; Bruno \& Sachs, 1982) argued an inverse relationship to exist between oil price increases and economic activities.

Hamilton's (1983) study, however, proved a dramatic increase in oil prices to have had occurred before the majority of economic recessions in the US after World War II. Subsequently, a large volume of literature has examined the relationship between oil prices and economic growth for a number of industrial countries using vast theoretical connections.

Mork (1989) proposed to examine asymmetric shocks by dividing real oil price changes into two aspects: upward and downward. He found the effects of oil price increases to differ from oil price decreases, with oil price decreases in the USA being statistically insignificant. Similarly, Hooker (1996) found a rise in oil prices to have caused no changes to macroeconomic indicators in the USA from 1973 to 1996.

Jimenez-Rodrigues and Sanchez (2004) examined oil price fluctuations' effect on GDP growth in OECD countries using the Granger causality test. With regard to oil importing countries, oil price increases were found to negatively affect economic activities in all the countries covered in the study apart from Japan. They also found the effect oil price changes have on GDP growth to be different in the United Kingdom and Norway. Although both of these countries are oil exporters, oil price increases had negatively affected the UK and positively affected Norway.

Lee and $\mathrm{Ni}$ (2002) discussed the possible effects oil price fluctuations can have on supply and demand in different countries. As a result of their research, they found oil price shocks to principally lead to a supply reduction in countries with large cost shares of oil; for the rest of countries, oil price shocks principally lead to a demand reduction.

Balcilar et al. (2010) examined the effect oil price fluctuations have on South African GDP growth using the Bayesian Markov-switching VAR analysis. Their result showed oil price changes to have caused changes in real GDP growth for low growth regimes, with higher growth regime being able to last longer than lower growth regimes.

Narayan et al. (2014) examined the connection between oil prices and economic growth for 28 developed and 17 developing countries. They used predictability tests that took into account key characteristics of the data such as persistence, endogeneity, and heteroscedasticity. They found evidence showing nominal oil prices to predict economic growth in 16 developing countries and 21 developed countries. The in-sample predictability was found to be unrelated to the use of nominal and real prices, which revealed a significant affirmation of the existence of predictability in developed countries.

Hakro and Omezzine (2016) investigated these relationships in Oman between 1980 and 2010 using the SVAR method. Their analysis results imply the longterm changes in oil prices to have affected output growth and the policies implemented in the Oman economy.

Fititi et al. (2016) examined the link between oil prices and economic growth for the four biggest oil exporting countries in the Organization of Petroleum Exporting Countries (OPEC): United Arab Emirates, Kuwait, Saudi Arabia and Venezuela. The study covered the period between 2000 and 2010. Their results suggested changes in oil prices and/or outbreak of a financial crisis to have led to changes in economic activities in these OPEC member countries.

Akalpler and Nuhu (2018) analyzed the effects oil price instability had on economic growth in Nigeria for the period 1981-2015. The results obtained using the vector error correction model confirmed that oil prices have a positive correlation with real effective exchange rates and economic growth and that government 
spending and inflation negatively affect growth. The time series of oil prices had resulted in economic growth and a higher exchange rate, while the exchange rate time series had resulted in inflation. Variance decomposition results confirm oil price instability as the main cause for the change in economic growth and exchange rate, while the biggest change in inflation rate had resulted from the instability in the exchange rate and oil prices.

Olayungbo (2019) examined the effect oil revenue had on Nigeria's economy. He used the Bayesian timevarying parameter model to see if the resource curse was present in Nigeria using annual data from 1970 to 2015; the results show oil export revenues to have had a positive and significant effect on economic growth in Nigeria during the examined period.

Bergmann (2019) examined the effect of oil price fluctuation on GDP growth for 12 countries using linear and nonlinear VAR models. The results show a decline in oil prices to have led to a nonlinear effect; in other words, oil prices have a weak causal effect.

Grigoli et al. (2019) sought to explain the short-term effects from the 2014-2016 drop in oil prices in oil exporting countries. They found the oil exporting countries that had experienced positive effects to have had some factors (e.g., higher foreign reserves, good fiscal position, diversified economy, flexible exchange rate, price stability) that helped them avoid the negative effects of oil price decreases. They also found the effects of oil price decreases to be unrelated to economic activity, magnitude of oil exports, and the fiscal revenue's oil shares.

Jarrett et al. (2019) examined the interactions among oil price volatility, financial institutions, and economic growth over 30 oil exporting countries. They found that the impact changes in oil prices had on growth to be able to be reduced through good financial institutions. In other words, the results support the case of good financialinstitutions having a positive role in fostering growth and improving energy security.

Mo Bin et al. (2019) examined the impact changes in oil prices have on economic growth in BRICS countries. They confirmation the presence of a heterogeneous impact in BRICS countries over the periods and subperiods due to the various economic developments and oil policies BRICS countries had implemented. They also found the effect in these countries to be positive.

Maheu et al. (2020) examined the connection between oil prices and changes in economic growth using a number of oil-price shock measures. They found that oil-price shocks had not affected the conditional mean of economic growth but had had a significant robust effect on the conditional variance of economic growth.

Hidayat and Sakti (2020) analyzed the effects of oil prices from a different perspective. They studied oil prices in the context of their interactions with banking profitability in 81 Islamic banks between 2006 and 2015 and found oil price increases to affect around $4.2 \%$ to $4.8 \%$ of profitability.

Only a few studies are found to have investigated the relationship between oil price and economic growth in Chad. Ndoumtara (2007) examined oil price increases in Chad and the risks of Dutch disease using a calculable model based on general equilibrium theory. The results show contractions to occur in the manufacturing sector, growth in the building and service sectors, and increase in imports as oil price increase, and increase urban migration to lead to the development of consumer society but not to the development of a production society.

Abakar (2018) evaluated the resource curse in Chad's economy by critically investigating the effects oil revenues have on Chad's economic and social development using tables. According to author, the decline in oil demand in 2016 reduced the country's exports and imports of services and goods as countries had been heavily dependent on oil exports. Most investments in Chad had come from the oil sector, and foreign direct investment had declined sharply alongside the decline in investments in the oil sector.

Gadom et al. (2018) used the multidimensional wellbeing index (MDW-index) to analyze the effects oil revenues have on welfare in Chad. The authors employed two surveys INSEED had performed in 2003 and 2011. The findings showed the departments that had received significant oil transfers in Chad to have a higher MDW-index value than those that had lower oil revenues. In order for Chad to develop its economy, Chad authorities must improve oil revenue redistribution systems and distribute oil revenues to the poorest sectors and according in accordance with local developmental needs.

As can be seen in the literature, several studies are found to have investigated relationships in different types of economies with mixed results. Moreover, studies investigating the effects of oil reserves and prices on Chad's economy have employed surveys, comparisons, and table analyses. This might result from insufficient data belonging to Chad. In this regard, we will study data from the 1963-2019 period, which covers both its oil importing and oil exporting eras. Moreover, we will employ the method of rollingwindow regression and causality analysis developed by Balcilar et al. (2010) in order to obtain exact results regarding possible interactions. By doing so, we will ul timately be able to compare two eras.

In light of these explanations, the main contributions from this study are an examination of the impacts oil prices have had on Chad's economy using times series analyses and a comparison of the two eras should any asymmetrical factors be found between them. To our 
knowledge, this is the first study to analyze Chad's economic situation in the post-oil era.

\section{OIL'S EFFECTS ON CHAD'S ECONOMY}

The economy of the Republic of Chad had for nearly 40 years before the oil project been structurally based on primary and tertiary sectors, albeit at very low values. The agricultural sector supports $80 \%$ of the population and is largely informal and particularly sensitive to climate change. In general, inadequate rainy seasons have been one of the most important reasons for the decline in production (APE Tchad, 2006, pp. 34-37).

Chad's industrial production is limited to cotton, sugarcane, and gum Arabic. Cotton has a significant economic and social weight for Chad and its rural population as it employs about 2 million people. Sugarcane is the second industrially used agricultural product. Chad Sugar Company's payroll is approximately 4 billion CFA francs and this company pays 8 billion CFA franc annually. Meanwhile, gum Arabic is mainly used for export in the pharmaceutical, chemical, and cosmetic sectors and constitutes Chad's third largest export item; it employs approximately 200.000 people (APE Tchad, 2006, pp. 39-43).

The economy of Chad is mainly driven by the primary sector, which had been dominated by livestock and agriculture (e.g., cotton, grains, sesame, and gum Arabic) before the oil era. Between 1960 and 1979, the primary sector represented $40 \%$ of the GDP. In the 1980 s, this amount averaged out at $35.3 \%$, then increased slightly, representing $38.2 \%$ of the GDP between 1991-2000. With the primary sector representing $55.75 \%$ of the average GDP between 2001-2009, this increasing trend is seen to have also continued into the oil era (Doujidingao, 2017, pp. 6-7).

At the beginning of 2000 , the construction of an oil infrastructure and the entry of the first oil income into the 2003-2004 state budget changed the superiority of the primary sector in Chad's GDP. The petroleum sector comprised approximately $70 \%$ of budget revenues and $80 \%$ of basic product exports between 2004-2014. Thus, oil had become the main engine of the Chad economy (Doujidingao, 2017, p. 7).

In 2018 , Chad's oil sector represented about $85 \%$ of all exports, $40 \%$ of public revenues, and $15 \%$ of the real GDP. The poor use of oil income led to Chad being unsuccessful at achieving long-term economic growth; as a result, the economy became less diversified (Kitzmuller et al., 2018). In addition, the financing available for major structural reforms has been destabilized repeatedly due to oil price fluctuations.

Once Chad started exporting oil, its economic performance gradually improved. The 2003-2014 period is characterized with positive shock. Chad's per capita GDP increased from \$331 US in 2003 to \$1,025 US in 2013 (see Figure 2). Since 2015, Chad's economic activity has declined sharply due to the decline in oil prices and a tense security situation (i.e., Boko Haram in neighboring countries).

Figure 2. GDP per capita of Chad*

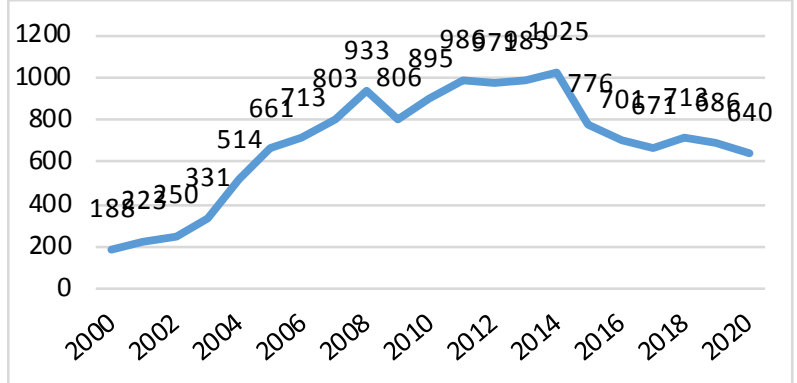

*(2000-2020 Current prices US\$).

Source: IMF Data Base (Access date: 01.03.2020).

The international decline in oil prices and the deteriorating regional security situation caused Chad's real GDP growth to decline from $6.9 \%$ in 2014 to $-6 \%$ in 2016 (see Figure 3). As a result of Chad's oil prices dropping from \$110 US in 2014 to \$36 US in 2016, investments in oil also fell by more than $80 \%$ and the non-oil GDP shrank by 6\% in 2016 (see Figure 4). In 2017, unexpected oil production shortages led to a rather poor performance from the oil sector; however, prices started to recover toward the end of 2017.

Figure 3. Chad's Real GDP between 2000-2020*

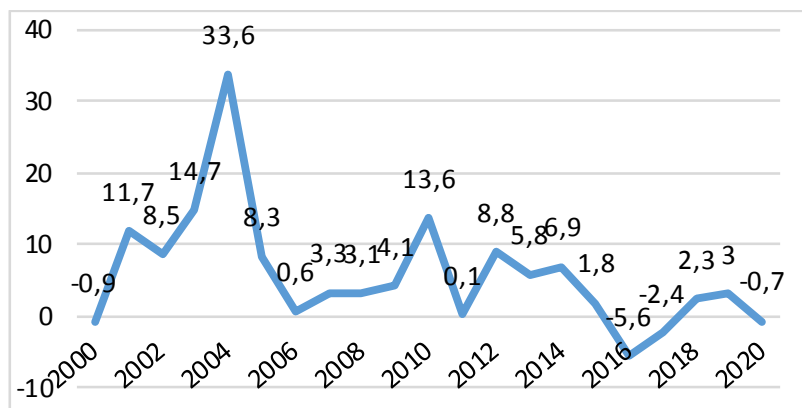

*(Annual change in percentage).

Source: IMF Data Base (Access date: 01.03.2021).

Chad has been slowly recovering from a severe recession since the end of 2017. Economic growth was $2.3 \%$ in 2018 and reached 3\% in 2019 due to increased oil and agricultural production.

Figure 4. Chad's Real non-oil GDP Growth

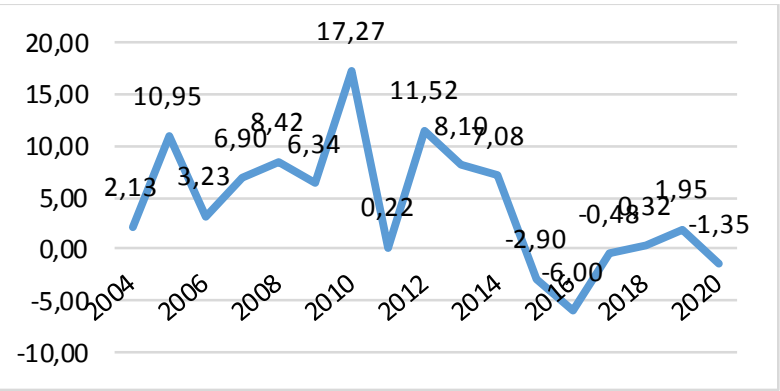

*(Annual change in percentage).

Source: IMF Data Base(01.03.2021). 
In 2018, Chad made an agreement with an international commercial creditor (Glencore), which significantly renovated debt sustainability and improved Chad's liquidity. This accord involves a significant time extension, lower interest rate, and large reduction in restructuring fees. The agreement also contains an odds mechanism that allows the Glencore external debt service to be reduced when oil prices fall. While Chad's debt currently appears to be less vulnerable against oil price fluctuations and more sustainable, the distress from foreign and general debt continues to be high. These sensitivities are expected to increase with the COVID-19 outbreak and the fall of Brent oil prices to $\$ 40$ US per barrel in June 2020 (Campagne et al. 2020, p. 5). As a result, Chad's economy shrank by $1 \%$ in 2020, and Chad's non-oil GDP shrank by $1.35 \%$.

Due to high oil export gains in 2019, Chad's external position strengthened. Chad oil prices increased from $\$ 49$ US in 2017 to $\$ 58.8$ US in 2019, and oil production reached 9 million barrels. In 2019, exports saw a $5.2 \%$ growth rate while imports capped at a $3.9 \%$ growth rate.

Before the COVID-19 outbreak, Chad's economic performance had continued to improve. The non-oil economy continued to recover with high public investment and domestic debt repayment, as well as recovery in cotton and livestock farming; non-oil GDP had grown by $1.95 \%$. In addition, contraction in the current account deficit occurred due to the decrease in FDI imported for oil sector developments.

Amid the COVID-19 outbreak and the sharp drop in international oil prices, Chad's economy has changed radically and could get worse, especially if the crisis is worse than expected. In 2020, its GDP had contracted by $0.7 \%$ and it non-oil GDP by $-1.5 \%$.

As a result of the COVID-19 outbreak, Chad's non-oil economy has been affected by several factors (International Monetary Fund, 2020, p. 7). One is the decline in trade and finance remittances; with the containment actions taken against the epidemic, the slowdown in economic activity and customs and domestic tax revenues are expected to decrease, resulting in government revenue decreases. In the event of a prolonged pandemic, foreign investment in Chad will drop, which may negatively affect Chad's growth. Due to the impact COVID-19 has had on small and medium-sized enterprises, their credit performance may be affected, and banks' asset quality and liquidity may deteriorate.

Overall, Chad's economy is very vulnerable to macroeconomic shocks, especially to oil price fluctuations. As a result, the constant dependence on oil has made the economy less diversified, less competitive, and more vulnerable to external shocks. More recently, after the 2015 oil shock, Chad has experienced a deep recession and severe macroeconomic imbalances.

\section{EMPIRICAL ANALYSIS}

The main problem with Chad's economy is the lack of several data at different frequencies. For this reason, the study employs annual data on economic growth and oil prices. The period the study covers is between 1963 and 2019. In order to measure oil price fluctuations, the study employs WTI per-barrel oil prices and takes the natural logarithm of the oil price series. On the economic growth side, the study employs gross domestic product (GDP) and differentiates the growth rate from the real gross domestic product.

The first step checks the variable movements in Figure 5. A lagged response of economic growth can be seen in terms of oil price fluctuations over the 2004-2019 period, which is Chad's oil era. According to Fig. 5, economic growth had a negative response to the reduction in oil prices. Before the oil era, this relationship was weak, and no conclusion can be made about the interaction being positive or negative. For this reason, employing econometric methods is the best way to get more robust results.

The main problem with Chad's economy is the lack of high-frequency data such as quarterly or monthly values. As such, analyze the oil era between 2004 and 2019 is not possible. To be able to perform an econometrical comparison, the rolling-window regression and causality analysis methods developed by Balcılar et al. (2010) have been used.

Figure 5. Oil Price Trends (Log) and GDP Growth (\%) 1990-2019

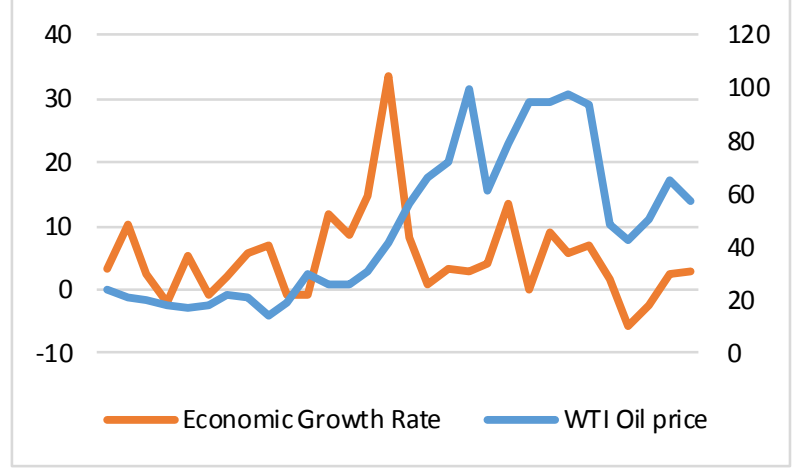

The first step employs the rolling-window causality analysis. The results imply that causality had appeared during a specific time period. The results are presented in Figure 6, according to which the causation linkage from oil price to economic growth is shown to be valid for the 2002-2005 period when the oil era started. Moreover, a causation tie also appears in 1997. Despite 1997 not being significant in theory, the 2002-2005 period is significant in terms of oil discoveries being present in the economy. As the result shows $p$ under the $10 \%$ significance level, the null hypothesis is 
accepted, and the alternative hypothesis is rejected except for the 2002-2005 period and 1997.

Figure 6. Rolling-Window Causality Analysis Results.

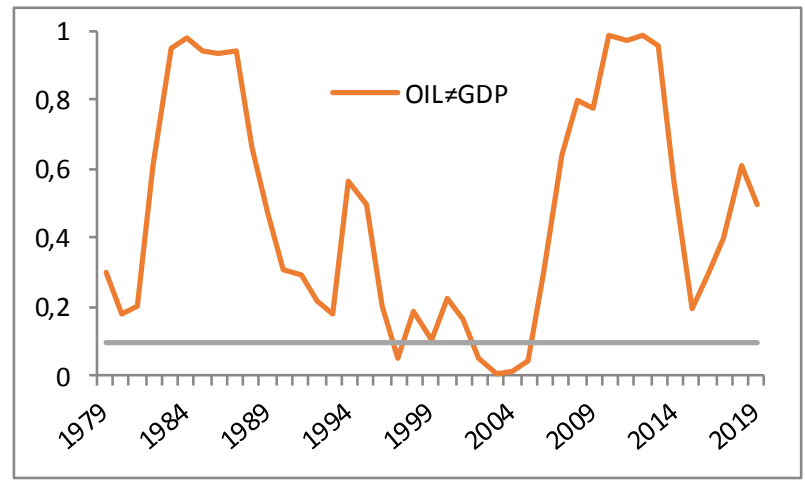

The second step employs the rolling-window regression analysis using the same data. Employing the regression analysis provides information about the coefficients regarding how oil prices affect economic growth. The simple model for measuring the effect oil prices have had on Chad's economic growth is as follows:

$G D P=a+b \mathrm{GDP}$

According to the rolling-window regression analysis results, the sign of the coefficient changes over time. The results are presented in Figure 7 . Significant coefficients are found between 1979 and 2019; between 1979 and 1997, the coefficient is negative. This means a rise in oil prices reduces Chad's economic growth performance. When comparing this result, economic growth can be concluded to have been affected by oil prices as explained in the theoretical framework. Meanwhile, the coefficient has positive values between 1997 and 2017. This indicates that oil price increases had positively affected Chad's economy. When checking the lower and upper bounds of the coefficient, the lower bound is still negative between 1997 and 2003. Oil prices' positive effects on economic growth can be prominently seen between 2003 and 2008 in terms of the magnitude of the coefficient. In 2018 and 2019, the coefficient becomes negative again.

Figure 7. Rolling-Window Regression Analysis Results

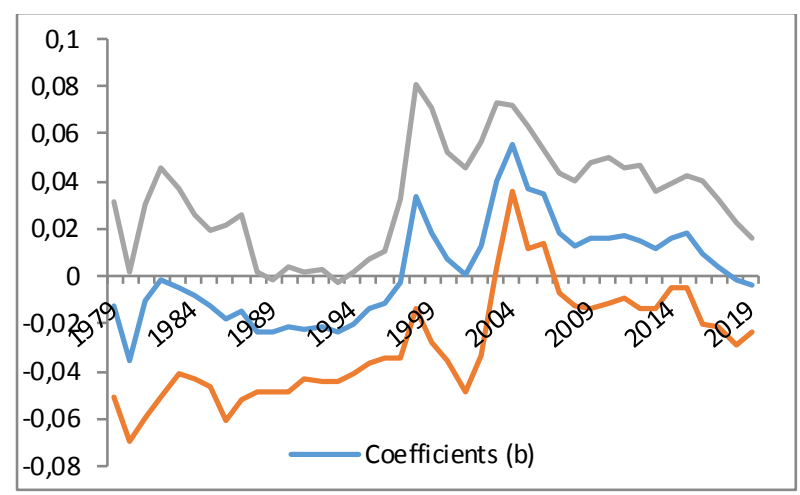

\section{CONCLUSION}

This study examines the effects of oil price fluctuations on Chad's economy from 1963 to 2019 using the rolling-window regression and causality analysis developed by Balcilar et al. (2010). The study contributes to the literature by examining the impacts oil prices have had on Chad's economy using a time series analysis and by comparing the two eras for any asymmetries between them. This study is one of the first studies to analyze Chad's economic situation following its oil era.

The first step was to analyze the economy using figures to see the connection between oil prices and economic growth during the oil era from 2004-2019. The results show economic growth to have reacted negatively to a reduction in oil prices. Because this relation had been weak during the pre-oil era, drawing conclusions about the direction of the interactions is not possible. For this reason, the rolling-window regression and causality analysis developed by Balcılar et al. (2010) has been used in the second step in order to be able to perform an econometric comparison. The results from the causality analysis show causality from oil prices to GDP to only be present in 1997 and during the 2002-2005 period. However, according to the rolling-window regression analysis, the results show the coefficient to have been negative during the 1979-1997 period, which means increases in oil prices had reduced Chad's economic growth. On the other hand, the coefficient is positive during the 1997-2017 period, which indicates oil price increases had had a positive effect on Chad's economy.

The discovery of oil reserves in Chad can be considered as an important opportunity. As can be seen, this was due to Chad having had an energy-dependent economy, which can be harmful for an economy during volatile periods in terms of energy prices. After the discovery of oil reserves, oil prices are seen to have induced economic growth into the Chad economy through oil revenues. Although the magnitude of oil price had a limited impact on Chad's economy, the Chad government may be able to increase it by using its oil revenues efficiently. In this regard, the Chad government must implement policies supporting the efficient use of oil revenues. These can improve institutional governance and support education systems for increasing human capital. By doing so, resources will be used more efficiently and accelerate economic growth. Otherwise, the negative effects oil has had on the economy will continue to be seen in the context of theoretical and empirical explanations, such as Dutch disease and resource curse theories. In this regard, the negative coefficient over the last two years can be a sign of the validity of the resource curse hypothesis. This makes institutional reforms more essential within Chad's economy. 


\section{REFERENCES}

Abakar, M. S. (2018). The effects of oil on economic development of Chad. Journal of International Trade, Logistics and Law, 4(1), 23-30.

Akalpler, E., \& Nuhu, A. B. (2018). The impact of oil price instability on economic growth: Evidence from Nigeria, business. Economics and Management Research Journal, 1(1), 39-53.

Aouzal, L. L. (2018). Impact de dynamique des cours de pétrole sur la croissance économique au Maroc. International Review of Economics, Management and Law Research, 1(1), 1-22.

APE Tchad- strictement confidentiel (2006). Etude d'impact, d'un accord de partenariat économique (APE) entre la Communauté Economique des Etas de I'Afrique Centrale el I'Union Européenne sur l'économie du Tchad, Rapport Final, Group ACP, Terta Stratégie \& Conseil.

Balcilar, M., Ozdemir, Z. A., Bakü. \& Arslantürk, Y. (2010). Economic growth and energy consumption causal nexus viewed through a bootstrap rolling window. Energy Economics, 32(6), 1398-1410.

Bergmann, P. (2019). Oil price shocks and GDP growth: Do energy shares amplify causal effects? Energy Economics, 80, 1010-1040.

Bernanke, B. S. (1983). Irreversibility, uncertainty, and cyclical investment. The Quarterly Journal of Economics, 98(1), 85-106.

Bruno, M., \& Sachs, J. (1982). Input price shocks and the slowdown in economic growth: The case of U.K. manufacturing. Review of Economic Statistics, 49(5), 679-705.

Campagne, B., Kitzmuller, M., \& Tordo, S. (2020). Designing oil revenue management mechanisms: An application to Chad. Policy Research Working Paper 9402. World Bank Group.

Darby, R. M. (1982). The price of oil and world inflation and recession. American Economic Review, 72(4), 738751.

Doudjidingao, A. (2017). Rapport d'analyse du contexte socioéconomique en vue de la mise en œuvre du projet au Tchad, Rapport national d'évaluation Mars, CNUCED.

Edelstein, P., \& Kilian, L. (2009). How sensitive are consumer expenditure to retail energy price? Journal of Monetary Economics, 56, 766-779.

Fititi, Z., Guesmi, K., Teulon, F, \& Chouachi, S. (2016). Relationship between crude oil price and economic growth in selected OPEC countries. Journal of Applied Business Research, 32(1), 11-22.

Gadom, D. G., Kountchou, A. M., \& Arar, A. (2018). The impact of oil revenues on well-being in Chad.
Environment and Development Economics, 23, 591613.

Ghalayini, L. (2011). The interaction between oil price and economic growth. Middle Eastern Finance and Economics, 13, 127-141.

Grigoli, F., Herman, A., \& Swiston, A. (2019). A crude shock: Explaining the short-run impact of 2014-2016 oil price decline across exporters. Energy Economics, 78, 481-493.

Gylfason, T. (2000). Resources, agriculture, and economic growth in economies in transition, CESifo Working paper, No. 313. Center for Economic Studies and ifo Institute (CESifo). Munich.

Hakro, A. N., \& Omezzine, A. M. (2016). Oil price effects on exchange rate, output and consumer price: A case study of small open economy of Oman. Journal of Economic Cooperation and Development, 37(3), 1-28.

Hamilton, J. D. (1988). A neoclassical model of unemployment and business cycle. Journal of Political Economy, 96(3), 593-617.

Herrera A. M., Mohammad B. K., \& Sandeep, K. R., (2019). Oil price shocks and U.S. economic activity. Energy Policy, 129, 89-99.

Hidayat, S. E., \& Sakti, M. R. P. (2020). Oil prices and Islamic banks performance in the OIC countries: Evidence from the Dynamic GMM approaches. Journal of Economic Cooperation and Development, 41(2), 113140.

Hooker, A. M. (1996). What happened to the oil pricemacroeconomy relationship? Journal of Monetary Economics, 38(2), 195-213.

International Monetary Fund. (2015, October). Where are commodity exporters headed? Output growth in the aftermath of the commodity boom. World Economic Outlook (Ch. 2).

International Monetary Fund. (2020, April). Requests for disbursement under the rapid credit facility, extension of the extended credit facility arrangement, and rephasing of access CHAD. IMF Country Report No. 20/134.

Jarrett, U., Kamiar, M., \& Hamid, M. (2019). Oil price volatility, financial institutions and economic growth. Energy Policy, 126, 131-144.

Jimenez R. R., \& Sanchez, M. (2004). Oil price shocks and real GDP Growth: Empirical evidence from some OECD countries. Working paper series No. 362/ May. European Central Bank.

Kitzmuller, M., Matta, S., N., Kassim, O. M., Nyman, S., Koschorke, J. A., \& Gebregziabher, F. H. (2018). Comment le Tchad peut-il sortir du labyrinthe de la croissance ? Démêler les contraintes des opportunités 
et trouver la voie d'une croissance durable. Washington, DC: World Bank Group.

Maheu, J. M., Yong S., \& Qiao ,Y. (2020). Oil price shocks and economic growth: The volatility link. International Journal of Forecasting, 36, 570-587.

Mo B., Cuiqiong C., He N., \& Yonghong, J. (2019). Visiting effects of crude oil price on economic growth in BRICS countries: Fresh evidence from wavelet-based quantile-on-quantile. Energy, 178, 234-251.

Mork, A. K. (1989). Oil and the macroeconomy when prices go up and down: An extension of Hamilton's results. Journal of Political Economy, 97(3), 740-744.

Narayan, P. K., Susan S., Wai, C. P., \& Joakim, W. (2014). Do oil prices predict economic growth? New global evidence. Energy Economics, 41, 137-146.

Ndoumtara, N. (2007). Boom pétrolier et risque d'un syndrome hollandais au Tchad : Une approche par la modélisation en équilibre général calculable (Doctoral dissertation). Université d'Auvergne Clermont Ferrand I.

Olayungbo, D. O. (2019). Effects of oil export revenue on economic growth in Nigeria: A time varying analysis of resource curse, Resource Policy, 64, 101469.

Rasche, H. R., \& Tatom, J. A. (1977). Energy resources and potential GNP. FederalReserve Bank of St. Louis Review, 59(6), 10-24. 